\title{
University educational management and clinical practice applied to nursing by the faculty of a public university
}

\author{
Gestão educacional universitária e prática clínica aplicada à enfermagem por docentes em uma universidade pública
}

Gestión educativa universitaria y práctica clínica aplicadas a la enfermería por maestros en una universidad pública

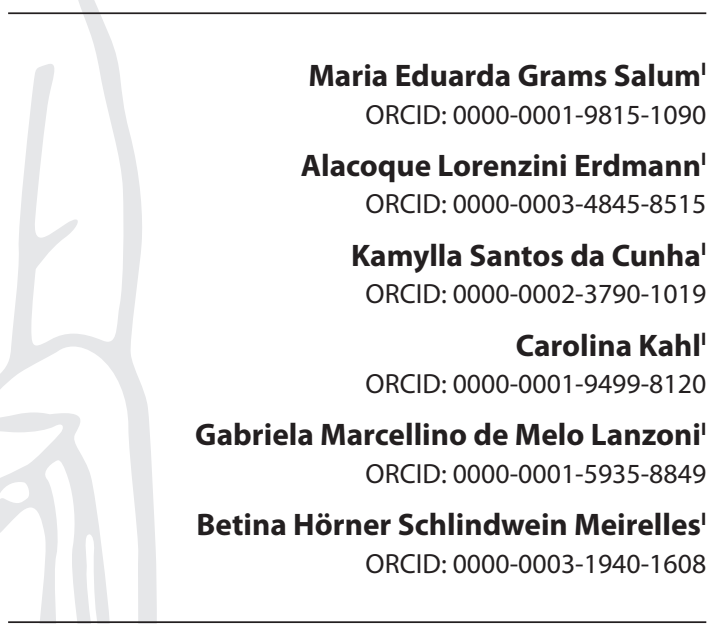

'Universidade Federal de Santa Catarina. Florianópolis, Santa Catarina, Brazil.

How to cite this article: Salum MEG, Erdmann AL, Cunha KS, KahI C, Lanzoni GMM, Meirelles BHS. University educational management and clinical practice applied to nursing by the faculty of a public university. Rev Bras Enferm. 2020;73(6):e20180909. doi: http://dx.doi.org/10.1590/0034-7167-2018-0909

Corresponding author:

Maria Eduarda Grams Salum E-mail: dudasalum1@gmail.com

EDITOR IN CHIEF: Dulce Barbosa ASSOCIATE EDITOR: Alexandre Balsanelli

Submission: 01-23-2019

Approval: 05-10-2020

\section{ABSTRACT}

Objective: to emphasize university educational management actions and their articulation to develop clinical practice in nursing training, designed by its faculty. Methods: a single-case study with qualitative approach. The sources were composed of documentary research, focused interview with key informant and direct non-participant observation. Data were organized with the help of NVivo 10 . Analysis followed the explanation construction technique from the perspective of complex thinking. Results: three categories emerged: Characterization of university educational management actions; Articulation of university educational management with clinical practice and its repercussion; and Spaces to develop university educational management and clinical practice. Final considerations: university educational management actions are associated with the work of professors, supporting teaching, research, and extension in order to improve clinical knowledge in the general nursing training.

Descriptors: Clinical Competence; Education, Nursing; Universities; Faculty; Nursing.

\section{RESUMO}

Objetivo: evidenciar as ações de gestão educacional universitária desenvolvidas por docentes enfermeiros e a articulação dessas para o desenvolvimento da prática clínica na formação de enfermeiros. Métodos: estudo de caso único, com abordagem qualitativa. As fontes foram compostas por pesquisa documental, entrevista focada com informante-chave e observação direta não participante. Os dados foram organizados com o auxílio do software NVivo 10, e a análise seguiu a técnica de construção da explanação sob a ótica do pensamento complexo. Resultados: emergiram três categorias: Caracterização das ações de gestão educacional universitária; Articulação da gestão educacional universitária com a prática clínica e sua repercussão; e Espaços para o desenvolvimento da gestão educacional universitária e da prática clínica. Considerações finais: as ações de gestão educacional universitária são inerentes ao trabalho do docente, subsidiando o ensino, pesquisa e extensão, a fim de aprimorar o conhecimento clínico na formação generalista de enfermeiros.

Descritores: Competência Clínica; Educação em Enfermagem; Universidades; Docentes; Enfermagem.

\section{RESUMEN}

Objetivo: destacar las acciones de gestión educativa universitaria desarrolladas por docentes de enfermería y su articulación para el desarrollo de la práctica clínica en la formación de enfermeras. Métodos: un estudio de caso único con un enfoque cualitativo. Las fuentes estaban compuestas por investigación documental, entrevistas enfocadas con informantes clave y observación directa no participante. Los datos se organizaron con la ayuda del software NVivo 10, y el análisis siguió la técnica de construcción de la explicación desde la perspectiva del pensamiento complejo. Resultados: surgieron tres categorías: caracterización de acciones de gestión educativa universitaria; Articulación de la gestión educativa universitaria con práctica clínica y su repercusión; y Espacios para el desarrollo de la gestión educativa universitaria y la práctica clínica. Consideraciones finales: las acciones de gestión educativa universitaria son inherentes al trabajo del docente, subsidiando la enseñanza, la investigación y la extensión, con el fin de mejorar el conocimiento clínico en la formación general de las enfermeras.

Descriptores: Competencia Clínica; Educación em Enfermaría; Universidades; Docentes, Enfermería. 


\section{INTRODUCTION}

Federal public universities are organized into sectors such as Dean's Office, Vice-Dean's Office, secretariats, teaching centers, departments and course coordination, and deliberative bodies. University organizational sectors join efforts to guarantee the functioning and development of training spaces based on teaching, research, and extension. In this context, university educational management can be interpreted as a process transposed by different elements, for instance, public policies, strategies and organizational policies, and social, cultural and historical contexts. Managers are demanded to have a look and actions directed beyond the bureaucratic and administrative aspects, taking them into account for effective management and maintenance of university education in the context of research, teaching, and extension, providing training spaces of excellence ${ }^{(1)}$.

University educational management has as main product the impact of production of technological, scientific, humanistic, and artistic knowledge in the various sectors of society, contributing to the development of solutions to the main problems of society through technological and scientific innovations, strengthening the country's social and economic development. Through teaching, research, and extension inseparability, public universities maintain their university commitment to society by training and qualifying professionals through the use of pedagogical forms that effect interdisciplinarity, thus overcoming the dichotomy between subject-object, theory-practice, promoting and strengthening science and its respective professions ${ }^{(2-3)}$.

Therefore, as university educational management is a means of training for quality higher education, professors become one of the main agents to balance functioning, structure, and desired results. Teaching dimension can be understood from carrying out activities, tasks and functions that require mobilization of diverse attitudes, skills, and knowledge, such as didactic-pedagogical competence, behavioral competence associated with the pursuit of interpersonal relationships, competence to interpret educational legislation, competence associated with administrative functions to manage academic organizational processes, academic training in the specific field and mastery of methods and technologies necessary for educational management ${ }^{(4-5)}$. Thus, professors' work and, in this case, nursing professors, must align with the current settings of social, economic and political changes and articulate with the various activities under their coordination, such as those carried out by professors, administrative technicians and students ${ }^{(5)}$.

As nurses' professional performance becomes increasingly comprehensive, complex and recognized (a large numerical contingent being present in most health institutions, these professionals take on responsibilities for actions related to patient care, education and training of health professionals, and in the administrative-managerial scope, strongly impacting service quality), training education needs to be provided at an advanced level to meet the population's health/disease needs ${ }^{(6-7)}$. In this context, it is understood that the multiplicity of actions developed by professors is aligned with complex thinking, since it breaks with the linear idea of cause/effect or product/producer ${ }^{(8)}$, when university educational management makes use of all resources and articulations to enhance undergraduate students' technical and critical training, in this case, nurses.

Nursing undergraduate students demand skills and competences that articulate care with current scientific evidence, fully assisting users and families, and understanding their health/ disease needs ${ }^{(9)}$. The university educational management carried out by nursing professors provides construction of spaces where decision making and encouragement of clinical practice through development of prevention, promotion, protection and health rehabilitation actions are encouraged. Such actions aim to train professionals to serve the population in more diverse health settings, improving quality of life through comprehensive care and service, meeting the needs of users.

Considering the context presented: university educational management is an intellectual work and teaching, research and extension articulation actions developed by professors involves different political-pedagogical organizational structures; university educational management guarantees resources to plan, organize, control and lead the work and behavior of university staff and groups for training; university educational management actions must ensure the training of nurses with clinical and technical skills to meet the needs of society.

\section{OBJECTIVE}

To emphasize university educational management actions and their articulation to develop clinical practice in nursing training, designed by its faculty.

\section{METHODS}

\section{Ethical aspects}

The research complied with the ethical aspects of Resolution $466 / 12$ of the Brazilian National Health Council (Conselho Nacional da Saúde). The Research Ethics Committee with Human Beings submitted and approved the study.

\section{Type of study}

This is a single case study with qualitative approach, which seeks to investigate a contemporary phenomenon in depth in its context. The investigation was carried out by means of multiple data collection methods that assist in understanding the phenomenon's diverse faces and relationships ${ }^{(10)}$.

\section{Study setting}

The study was developed in a Department of Nursing at a federal public university in southern Brazil.

\section{Data source}

Data gathering took place through documentary research, focused interview with key informant and direct non-participant observation. The documentary research was carried out based on research and extension projects developed by faculty members with themes linked to clinical and complementary practice 
and their productions, included in Planning and Monitoring of Teaching Activities (PMTA) in 2017. Moreover, internal regulations, resolutions and norms of the university's undergraduate course, Department of Nursing, and council were used. They regulate the teaching, research and extension activities available on the respective bodies' and the university's office page.

The sample of interviews focused with key informants was composed of nine nursing professors, and this was the most important data source for the case study. It deals with behavioral events and human subjects, where interviewees provide important information about the situation studied in a short-time interview ordered by a set number of questions ${ }^{(10)}$. Professors were invited to participate in the interviews by invitation via e-mail. Before starting the interview, the research's objective was clarified as well as the reasons that led the researchers to investigate the theme.

Professionals assigned to the Department of Nursing, exclusive work employee, who having been occupying at least six months positions of coordination of main courses, teaching coordination, research, extension or internships have been included. In this study, the main courses are those in which educational actions are aimed at developing specific skills and abilities of nurses in different health care fields through theoretical and practical activities and contents, directing educational action in the various possibilities and experiences for to design competences associated with the profession, including clinical practice ${ }^{(11)}$.

Nursing professors away from work, for any reason, during data collection, have been excluded. After accepting to participate in the study and signing the Informed Consent Form (ICF), the interview's guiding question was "How do you characterize university educational management actions applied in teaching-researchextension developed by nurse professors and how do they articulate to develop clinical training for nurses?". Five teaching nurses did not participate in the study, of these, two did not return attempts to contact the invitation to participate, one was on sick leave and two chose not to do the interview due to activity overload. Of the fourteen professors who were eligible based on the inclusion criteria, the nine who agreed to participate in the research were interviewed, thus having to close due to exhaustion.

A direct non-participant observation was carried out in a meeting of coordinators of the main courses and coordinators of teaching, research, extension and internships in the Undergraduate Nursing Course. Request to participate in the meeting was made personally in previous contact with the coordinator of the course. The participating professors were informed about the purpose of the observation and its objectives, and after everyone's consent, those present signed two copies of the ICF. Field notes were made based on how university education management actions are articulated with clinical practice, convergences and divergences in decisions and which contexts were taken into account for university educational management articulation with clinical practice.

\section{Data collection and organization}

Data collection was carried out from December 2017 to May 2018 by extracting information from research and extension projects that had an interface with the clinical practice contained in the
professors'PMTA; specific details about the teaching, research and extension activities available in the internal regulations, resolutions, norms of the university's undergraduate course, Department of Nursing, and Council; focused and individual interviews with key informants carried out in the workplace and recorded on a digital voice device with an average duration of 35 minutes; non-participant observation, held in a meeting of coordinators of the axis courses and coordinators of teaching, research, extension and internships in the Undergraduate Nursing Course lasting four hours.

NVIVO 10 was used for ordering and organizing the data. The data obtained were grouped by similarities and into categories, in order to develop a structure for the case study, in addition to facilitating the identification of links between information, refining ideas and comparing details between categories ${ }^{(10)}$.

\section{Data analysis}

Data analysis took place from the perspective of complex thinking ${ }^{(8)}$, as it is understood that the knowledge of the parts depends on the knowledge of the whole, just as the knowledge of the whole depends on the knowledge of the parts. Therefore, in order to integrate the way of thinking and overcome knowledge linearity and fragmentation, the research context was studied in its entirety, and not just as the sum of its separate parts. After organization of the documents, transcription of the interviews and description of the observation, data were coded designating relevant concepts to answer the objectives of the study. Analytical categories were established, with the extraction of concepts grouped by similarities, identifying links between the information and the possibility of being assigned a theoretical meaning. Analytical strategy was guided through the theoretical propositions and the development of the case description. These strategies assist in the development of an analytical technique of construction of explanation, whose purpose is to explain the phenomenon, stipulating a set of causal links about it ${ }^{(10)}$.

From the triangulation of the data collected through documentary research, focused interview with key informant and direct non-participant observation, three categories emerged: Characterization of university educational management actions; Articulation of university educational management with clinical practice and its repercussion; and Spaces to develop university educational management and clinical practice.

\section{RESULTS}

\section{Characterization of university educational management actions}

Participants understood that, through university educational management actions applied to teaching, research and extension, it is possible to strengthen the teaching of clinical practice and the quality of professional training for future nurses, as shown below:

When l am going to propose some action, be it research or extension, my main concern is ahead, in the education of this student. There is no way to do research without it having to do with the extension. [...] because I understand that, if I do a research, it has to start from a need for practice that brings care closer. (E03) 
The teaching perspective was listed as challenging for the participants. There was a constant need for theoretical updates and adaptations in the dynamics of knowledge construction so that students can follow the subjects and understand the importance of these for the effectiveness of clinical practice in the performance scenarios. It should be noted that clinic is gradually introduced into professional training, where students are inserted in scenarios with different complexities, so that they can improve clinical techniques, knowledge and practice.

Preparing classes, organizing teaching plans and schedules, discussing new internship fields based on the number of students entering the phase and correcting tests and activities are teaching actions, demanding more time and attention from professionals. At the university level, it is these actions that structure and strengthen the institution, being sustained and improved by the inseparability of teaching, research and extension, with a structuring complex between these three fields.

Corroborating this, the analysis of documents highlights, through the regulation of internships in the Undergraduate Nursing Course, that teaching actions constitute everything from nursing care activities, such as direct care to the population, to the exchange of knowledge. Different technologies and administrative activities are used as planning actions involving material, organizational and personal resources.

In my experience, I realized that teaching requires many times more time and more specific attention. There are many actions focused on the issue of teaching, and it is these actions that bring life to the institution, but one cannot fail to consider that research and extension will validate teaching. (E06)

With regard to teaching, there must be a very high commitment from professors to assist students in developing clinical practice so that they can apply it later in care, and for this development, one must obviously have a theoretical and scientific basis. (E08)

Concerning research, during the observation made, the participants stated that projects are developed to assist and meet the demands arising from the daily practice of nursing, directly impacting the clinic and care provided to the population. This discussion arose during a demonstration on the need to encourage research, even in the face of reduced foreign investment. In addition, insertion of students in research groups and projects encourages apprehension and development of new knowledge and skills that concern scientific research, bringing students closer to scientific evidence and the preparation of scientific articles. The Normative Resolution, which provides for research activity at the university in question, is in line with the statements. It affirms that research constitutes production and innovation of knowledge through research proposals and projects developed in favor of the community, being a point of support and differentiation of the university.

We have the development of the research field both in international terms and in the country itself, which has put into question the qualification of nursing training and the possibility of intervention in the population's health situation in a stronger way. [...] the research product demonstrates that nursing has the potential to act in different fields with a great capacity to develop actions in different fields, such as health promotion, attention to chronic diseases. (E06)

With regard to university extension activities, the participants stated that the articulation between University, service and community magnifies and expands the students' view of knowledge and possibilities of action, expanding the vision previously directed only to the patient for the family, community and territory, carrying out social and health changes. Additionally, the documentary analysis pointed out, through the university's Normative Resolution, which has and establishes the regulatory norms for extension actions, that extension is an interdisciplinary, educational, cultural, scientific and political process. It promotes transformative interaction between the university and other sectors of society. The university extension actions aim to encourage and enhance the interchange relations between University and society in relation to the institution's objectives; provide mechanisms for society to use existing knowledge in carrying out its activities; preserve the knowledge produced by interaction between University and society; and to facilitate and improve knowledge articulation and operationalization arising from teaching and research for society. The university's responsibility to meet community needs is reinforced through outreach actions.

The actions aimed at the assistance that we carry out for teaching, research and extension are made with the objective of directly impacting clinical practice. These actions try to improve the teaching and assistance provided by future professionals. (E04)

\section{Articulation of university educational management with clinical practice and its repercussion}

The articulation between the university tripod for clinical training provides students with a range of opportunities that directly contribute to their professional training. Thus, there is the possibility for them to know the various fields of professional specialization through specialist professors, conducting research and integrating research laboratories with varied themes.

The opportunities that students have within the undergraduate course are diverse. The diversity of fields of research and extension, the training that all professors have, everyone has a doctorate, at first everyone knows how to conduct a research process, several research methods. (E01)

The inseparability of teaching, research and extension actions enables clinical training and the construction of professionals through global strategies, not only in actions unrelated to curriculum organization, but linked to the epistemological core of the undergraduate course. All of these actions are considered to produce knowledge. Teaching and learning are interconnected, as shown by documentary analysis carried out from the University's Graduate Nursing Program.

Furthermore, proper and ethical positioning before the health staff, patient and family, the sense of responsibility and the expanded view of the scenario, decision-making and the autonomous and safe clinic are differential aspects observed in the articulation of university educational management actions, with direct repercussions on the quality of care provided. 
This issue of autonomy, criticality of professionals is reinforced and they really have the knowledge to argue, to have a position, to be leaders and guide the service. Nurses having this clinical characteristic in their work is fundamental and differential. (E05)

Thus, respect for cultural diversity and plurality is required and mentioned in the analyzed Nursing Undergraduate Program. It is fundamental for a flexible, open and citizen training process, articulating the actions of the university tripod to value the different forms of knowledge; seeking to overcome discrimination, authoritarianism and exclusion; and recognize the multiple expressions of social and cultural life in professional practice and clinical practice.

Furthermore, the institution's differentials reflect and contribute positively to clinical training, such as the possibility that professors are constantly updating and improving their training through actions provided by the institution, as well as access to databases. On these platforms, several journals are available for access, with scientific evidence that directly contributes to the clinical practice donated by professors and, consequently, to knowledge construction.

Professors have the possibility to update themselves with courses and technical visits. So, they are able to improve their clinical practice in a perspective of qualification, of training [...] because, when you teach clinic, you expect that student to identify what this situation is and learn to answer this clinic with the nursing care. So, this nursing care is within the theoretical-methodological framework that professors have to have. (E07)

The Department of Nursing, as indicated in the internal regulations, has a coordination of continuing education whose mission is to prepare, apply, evaluate and constantly improve the department's continuing education policy. Among the competences are organizing and providing information on continuing education actions for the faculty, encouraging, organizing, coordinating and monitoring the development of continuing and integrative education activities of professors.

Among the factors that collaborate for the articulation of university educational management with clinical practice, the participants elucidated factors that potentiate such articulation, such as the integrated work of the teaching staff for carrying out and structuring teaching in order to improve the training of students; preceptor nurses for internships in practice settings who understand the importance of the teaching-service partnership for clinical training; advances in understanding the teaching-learning process as it is understood that the teaching process does not take place only in the classroom, but in different scenarios; discussions on best health practices in order to qualify professional training.

The way in which we have advanced in understanding the teachinglearning process contributes to the articulation of teachingresearch-extension activities and clinical practice as we are able to understand the theoretical-practical relationship a little better [...] the teaching-service integration process is also an important factor in the development of this tripod, and the emphasis on clinical training of nurses is a factor that contributes to the development of this integration. (E06)
Analysis of the course program emphasizes the agreement between the university and the city hall. This agreement aims to establish the development of a university-health system articulation model, aiming at the development of training and continuing education programs for human resources for health within the perspective of the Brazilian Health System (Sistema Único de Saúde, abbreviated SUS). Interinstitutional cooperation is configured as a cyclical process that maintains the balance between formal and informal processes of interaction, professional training and polishing of clinical practice.

The articulation of university educational management with clinical practice is permeated by some difficult aspects. Among them are high demand for bureaucratic activities to be carried out by professors, making the development of other university educational management activities unfeasible with the overload of these professionals; and scarcity of resources to make research and extension projects feasible. These are sometimes carried out by the professor's own financing.

Reduced number of professors in the course's teaching staff becomes an aspect that directly reflects the overload of hours and activities. This also occurs with high number of students per phase and little engagement and interest on the part of students with regard to obtaining knowledge and experiences. Thus, the development of clinical practice and effective learning are hampered.

Often, we go to the field with six, up to eight students, and with that it becomes impossible to develop clinical practice and the learning process with safety and quality for the patient, the student and the professor. (E02)

I feel little engagement from students; I think they need to be a little more concerned with this knowledge of nursing. Nursing is not only practical, our profession has a theoretical-scientific basis. [...] sometimes I talk to colleagues and it seems that more and more students are studying less, getting less involved with knowledge and the profession. (E08)

\section{Spaces to develop university educational management and clinical practice}

For the development of university educational management, spaces were mentioned as meetings of department and coordinators of core subjects. Referrals for the correct progress of the semester are carried out, in addition to the schedule for the following semester.

During direct observation not participating in a coordinators' meeting, it was found that issues related to class good performance, in general, are placed on the agenda, as well as aspects related to internship fields. The learning scenario was widely discussed, as it has repercussions on the development of clinical practice, aiming to improve aspects that may have been difficult and guaranteeing a good teaching-service relationship. In addition, dimensioning of students who will move forward in the courses is essential for good programming of activities and for the schedule of the following semester.

All management issues are discussed in the meetings with course coordinators, such as, for instance, schedule for the next semester, distribution of professors and number of students [...] and there 
are other management issues that you have to be approved at department meetings. (E01)

Among the physical spaces for carrying out university educational management actions, the participants spoke both in an individual interview and in a discussion during the meeting of coordinators on university spaces. These facilities are University Hospital; some public hospitals in Florianópolis and other cities; primary health care services linked to the university; scenarios of diverse research and fields of practice; and the location where different extension groups are held.

I believe that the spaces are closely related to what is offered at the University Hospital and in the basic public health network. (E05)

Regarding spaces to develop and improve clinical practice, places were listed, such as simulation laboratories of the Department of Nursing. In these spaces, it is possible to simulate health/ illness situations so that students know which actions to take and which nursing care to employ, in addition to the possibility of improving techniques and procedures, enhancing the skills and competences of future nurses. Moreover, the University Hospital was reinforced as an important space for the development of clinical practice, fundamental for the articulation of teachingresearch-extension actions with clinical training.

Thinking inside the university, we have a hospital where we are developing clinical practice, nurses are developing their work with all this knowledge that they have with clinical practice, there is also our laboratory where we try to develop clinical practice with the students. (E08)

Analysis of the Department of Nursing's internal regulations points out that it acts in the promotion and permanent articulation of nursing spaces at the university (structures involved in the undergraduate, graduate and University Hospital fields). She works in a set of efforts to strengthen nursing work and improve students' clinical practice.

\section{DISCUSSION}

Professors, when characterizing the actions of university educational management, highlighted the relevance of articulation of the teaching, research and extension axes for strengthening students' clinical practice. The interrelationship between these axes brings the university closer to the community, highlighting the social side of the academy. Through teaching actions, students are encouraged to reflect and seek new knowledge. Research is a means of thinking critically and producing new knowledge that can be applied in society through extension projects ${ }^{(12)}$.

As society's health needs change and change, professors need to be flexible and responsive to these changes. Quality university education is in fact the product of all the efforts made by professors. Professors seek through teaching management to articulate scientific research and extension programs with actions that focus especially on innovative solutions and adaptations in response to the complex demands of the labor market and society ${ }^{(13)}$ promoting the quality of nursing courses.
The findings of this study showed that the inclusion of students in research laboratories encourages the development of new knowledge and skills with regard to scientific research. Corroborating the above, the study was conducted in southern Brazil with 19 professors from the Departments of Nursing and Public Health. It was emphasized that the presence of students in extracurricular activities, such as research projects, extension, scientific initiation and participation in research groups, adds to the development of scientific skills ${ }^{(14)}$.

Research groups are in charge for the development of skills for scientific research and maturity to do so, enabling feedback on graduation, as the products from research can be used in the context of teaching ${ }^{(15)}$. A documentary study, which compared the profile of nursing research groups registered in the CNPq Directory in 2006 (251 groups) and 2016 (617 groups), points to an increase in the number of research group members. In 2016, 249 groups (40\%) had 18 to 34 participants, different from the reality observed in 2016 , where only 58 groups (23\%) had this number of members. In 2016, there was a significant participation of students in the research groups. Thus, $36 \%$ of the participants were undergraduate students, showing an increased interest in participation in the context of scientific research by university students ${ }^{(16)}$.

University extension, seen as a form of articulation between service/teaching, research and community, allows students to expand horizons regarding the possibilities of professional performance, enhancing the clinical practice of nurses. A study carried out in the state of Rio Grande do Norte, with 46 nursing students, revealed that they understood extension programs as spaces where they put into practice the knowledge acquired during graduation. They disseminated the knowledge generated within the university to society. This is a substantial aspect for the general training of nurses, considering the importance of clinical reasoning in view of the complexity of the human being ${ }^{(17)}$.

Likewise, a descriptive, transversal and mixed study, reveals the help of university extension in the face of improvement of communication techniques, experiencing in the extension practices the valorization of the construction of relationships and understanding of individuals as citizens. Moreover, participants characterized university extension as substantial for the refinement of critical-reflective thinking, considering social reality, clinical practice and teamwork for professional performance ${ }^{(18)}$.

As evidenced by the participants of this study, the articulation of university educational management actions within the scope of teaching, research and extension to clinical practice reflects and has a positive impact on the care provided to patients. Experiences that enable the development of clinical practice provide students with a sense of responsibility, reflective critical thinking, autonomy and self-confidence, as they perceive themselves as professionals with the health staff(19).

Furthermore, professor improvement and qualification through actions carried out by the university were seen as differentials for clinical training. Teaching performance requires continuous learning and vast knowledge, so that professors perceive their responsibility and role in teaching-learning process and using strategies that contribute positively to professional training, guiding the process of knowledge construction ${ }^{(20)}$. Moreover, it is understood as urgent the training of nurses who have interaction with others as a characteristic of their work. Nursing students 
must be prepared to develop critical and reflective attitudes and actions capable of overcoming knowledge fragmentation and linearity, strengthening the articulation of health knowledge and practices in order to enhance the impact of their health practice ${ }^{(21)}$.

Among the factors that favor the articulation of university educational management actions with clinical practice, the participants highlighted the relevance of preceptors in internship fields. Such preceptors understand the importance of clinical practice in student training and collaborate with this aspect. The findings of a study point out that preceptors must perform the roles of evaluator, educator and facilitator of clinical practice and learning, in addition to being protective, both for students and patients, meeting the expectations and needs of student training. Furthermore, constructive criticism and feedback are important, in addition to support for problem solving contributing to professional training and encouraging students to improve their knowledge ${ }^{(22)}$. Thus, early insertion of activities that make the practice of clinical practice possible has a positive impact on the training of students ${ }^{(23)}$.

Another favorable factor highlighted is the advances in understanding in teaching and learning. Since traditional teaching patterns do not correspond to the current needs of society in the face of constant social, cultural and political transformations, it is necessary that the training of nurses and the production of nursing knowledge accompany such changes, training professionals able to face them and exercise the profession to its fullest ${ }^{(8)}$. Therefore, constant enlargements and changes in pedagogical proposals and pedagogical restructuring in the curriculum of undergraduate courses are essential. They bring nursing practice closer to curriculum proposals to what is advocated in the Brazilian Education Guidelines and Bases Law (Lei de Diretrizese Bases da Educação Nacional). Autonomy, development of care and management skills and training of competent and criticalreflexive professionals are developed, going beyond just skills related to leadership and management and technical skills ${ }^{(23-24)}$.

Among the competences and skills indispensable to graduating students, according to the Brazilian National Curriculum Guidelines (Diretrizes Curriculares Nacionais) for the Undergraduate Nursing Course, there are decision making; aptitude to develop preventive actions; health promotion, protection and rehabilitation; verbal, non-verbal communication and writing and reading skills; administration and management, leadership, permanent education and ethical-political, technical-scientific and socio-educational skills. Therefore, the importance of understanding the teaching-learning process based on social and political advances and changes is strengthened ${ }^{(25)}$.

Although these factors contribute to the articulation of university educational management actions with clinical practice, professors often claimed to be stuck with high demands for bureaucratic activities, which could be overcome with the help of administrative technical servants in these matters. However, hiring these servers is quite difficult, making certain demands time-consuming due to the bureaucratic steps necessary to be followed ${ }^{(26)}$.

High rate of bureaucracy in teaching and overload of activities are factors that intertwined the articulation of university educational management with clinical practice, meeting the findings of a study carried out with professors at a university in southern Brazil. This study points out the elements that describe feelings of suffering experienced in teaching practice. They are the sum of activities, excessive bureaucracy, high workload, demands for a high level of concentration and attention and precariousness in the work environment, often expressing dissatisfaction and overloading professors ${ }^{(27)}$.

Also, the number of professors per phase must correspond to the needs and the number of students. This context, according to the participants, is not a reality, as the number of existing professors in the faculty is currently limited. Therefore, this reflects negatively on the overload of activities and excessive hours of classes, requirements of funding agencies, preparation of evaluations and constant meetings, as a study with the objective of analyzing the knowledge produced about teaching in higher education in nursing elucidates ${ }^{(28)}$.

Furthermore, the participants highlighted little engagement and interest of students in learning. The results of a São Paulo study carried out with 21 professors have been confirmed. Such study highlights the lack of interest in being a nurse perceived by students, an aspect that may be combined with the low remuneration of the profession, high demand for responsibilities in professional practice and devaluation and lack of recognition of the profession ${ }^{(29)}$.

Among the spaces where university educational management actions and clinical practice can be developed, teaching hospitals, services from the SUS Health Care Network (Rede de Atenção à Saúde) and clinical simulation laboratories were highlighted. In this perspective, these spaces influence the clinical learning of students. Such spaces provide different experiences and experiences, which enable the improvement of clinical practice and the strengthening of professional training. Furthermore, they strengthen elements such as responsibility and trust. Such elements are essential so that students feel valued and belong to the practice scenario, reinforcing the acquisition of respect and safety ${ }^{(30)}$.

Clinical simulation laboratory, also mentioned in the study, is a teaching tool widely used around the world for nursing education. It has recognized efficacy in the acquisition and assimilation of knowledge, in addition to the development of critical thinking and improvement of clinical practice ${ }^{(31)}$.

Following the context of teaching through simulation, a study showed that training and qualification of professors in the use of laboratories are essential for the correct and global use of available technologies. It emphasizes the need for a trained and appropriate professional to coordinate activities and assist the faculty on the best ways to use technology and incorporate simulations into clinical teaching. Moreover, through financing obtained by professors with research projects, it becomes possible to carry out preventive maintenance and acquire more mannequins and materials necessary for proper functioning of simulation laboratories, classrooms and research groups ${ }^{(31)}$. Thus, it is evident the magnitude of educational management actions in relation to clinical training.

\section{Study limitations}

This study is limited to representing only a specific setting for the development of university management actions articulated with clinical practice developed by teaching managers. Likewise, this research was carried out within the scope of educational university management, and the aspects of university management in their breadth were little explored and highlighted. 


\section{Contributions to nursing}

This study can contribute with subsidies for reflections of teaching nurses on the importance and repercussions of university educational management actions in the clinical training of future professional nurses who are safe, autonomous, critical-reflective and scientifically supported.

\section{FINAL CONSIDERATIONS}

The findings showed that university educational management actions are associated with the work of teaching nurses. Articulation of these in the context of teaching, research and extension becomes essential as it provides students with better conditions to improve clinical knowledge, ethical positioning before the health staff, a sense of full responsibility, autonomy and safe decision-making. Research groups and extension projects stood out as spaces that give students the opportunity to be inserted in different realities of the health system and to approach professionals and the community, expanding horizons and visualizing possibilities for professional performance.

Nursing training requires university education management to be efficient and effective, building and consolidating the profession's workforce. These actions follow social changes and advances, subsidizing the training of generalist nurses who articulate health practices and scientific knowledge, enhancing the assistance provided to meet the population's health/disease demands.

\section{FUNDING}

This study was sponsored by the Brazilian National Council for Scientific and Technological Development (Conselho Nacional de Desenvolvimento Científico e Tecnológico, abbreviated CNPq) through the Institutional Program for Scientific Initiation Scholarships (Programa Institucional de Bolsas de Iniciação Científica) sub-agreed by Universidade Federal de Santa Catarina (PIBIC/UFSC).

\section{REFERENCES}

1. Dewes A, Bolzan DPV. Gestão universitária a partir da narrativa de professores gestores de departamentos didáticos. Rev Gest Aval Educ. 2018;7(15):39-53. doi: 10.5902/2318133830806

2. Ribeiro RMC. The nature of university management: influence of political-institutional. Economic and cultural aspects. Rev Inter Educ Sup. 2017;3(2):357-378. doi: 10.22348/riesup.v3i2.7787

3. Puhl MJ, Dresch OI. O princípio da indissociabilidade entre ensino, pesquisa e extensão e o conhecimento. Dialogus [Internet] [cited 2020 Mar 23]:5(1):37-55. Available from: http://200.19.0.178/index.php/Dialogus/article/view/3991/728

4. Pinto TRGS, Martins S, Faria R. Meanings of the management concept in the superior course coordinators. Rev GUAL. 2019;12(1):49-72. doi: $10.5007 / 1983-4535.2019 \mathrm{v} 12 \mathrm{n} 1 \mathrm{p} 49$

5. Rodrigues $A C A L$, Villard BQ. Formação universitária do docente para a gestão universitária: uma análise indutiva dos professores gestores da pós-graduação stricto sensu da UFRJ. Rev FOCO [Internet]. 2017 [cited 2019 May 03];10(2):208-31. Available from: http://www. revistafocoadm.org/index.php/foco/article/view/408/233

6. Fang D, Bednash GD, Arietti R. Identifying barriers and facilitators to nurse faculty careers for PhD nursing students. J Prof Nurs. 2016;32(1):193-201. doi: 10.1016/j.profnurs.2015.10.001

7. Biff D, Pires DEP, Forte ECN, Trindade LL, Machado RR, Amadigi FR, et al. Cargas de trabalho de enfermeiros: luzes e sombras na Estratégia Saúde da Família. Cien Saúde Colet. 2020:25(1):147-58. doi: 10.1590/1413-81232020251.28622019

8. Morin E. Introdução ao pensamento complexo. $4^{\text {a }}$ edição. Porto Alegre: Sulina; 2011.

9. Costa RHS, Couto CSO, Silva RAR. Clinical practice of nurses in the family health strategy. Saúde (Santa Maria). 2015 [cited 2019 May 10];41(2):09-10. Available from: https://periodicos.ufsm.br/revistasaude/article/view/10841/pdf

10. Yin RK. Estudo de caso: planejamento e métodos. 4a ed. Porto Alegre: Bookman; 2010.

11. Barbosa SFF, Amante LN, Boehs AE. Guia dos estudantes do curso de graduação em Enfermagem. Florianópolis: Universidade Federal de Santa Catarina; 2008

12. Silva TL, Resende GSL. A docência no ensino superior: ensino, pesquisa e extensão. Rev Facisa [Internet]. 2017 [cited 2019 May 03];6(2):3240. Available from: http://periodicos.faculdadecathedral.edu.br/revistafacisa/article/view/219/157

13. Bvumbwe T, Mtshali N. Nursing education challenges and solutions in Sub Saharan Africa: an integrative review. BMC Nurs [Internet]. 2018 [cited 2019 May 03]17(3):2-11. doi: 10.1186/s12912-018-0272-4

14. Moraes A, Guariente MHDM. Garanhani ML, Carvalho BG. The nurse training in research in the undergraduate education: teaching perceptions. Rev Bras Enferm. 2018;71(suppl4):1648-56. doi: 10.1590/0034-7167-2017-0511

15. Lima LPS, Cortez CMM, Ribeiro MRR, Rothebarth AP, Cesário JB. O desenvolvimento da competência para pesquisa e a graduação de enfermagem: o papel dos grupos de pesquisa. Arq Cienc Saúde UNIPAR [Internet]. 2015 [cited 2019 May 03];19(3):171-7. Available from: http://revistas.unipar.br/index.php/saude/article/view/5547/3142

16. Erdmann AL, Peiter CC, Lanzoni GMM. Brazilian research groups in nursing: comparison of 2006 and 2016 profiles. Rev Gaúch Enferm. 2017;38(2):1-7. doi: 10.1590/1983-1447.2017.02.69051 
17. Oliveira FLB, Almeida Jr JJ. Extensão universitária: contribuições na formação de discentes de Enfermagem. Rev Bras Pesqui Saúde [Internet]. 2015 [cited 2018 Aug 02]; 17(1):19-24. Available from: http://periodicos.ufes.br/RBPS/article/viewFile/12445/8655

18. Ferreira PB, Suriano ML, Domenico EBL. Contribuição da extensão universitária na formação de graduandos de enfermagem. Rev Ciênc Ext [Internet]. 2018 [cited 2019 May 03];14(3):31-49. Available from: http://ojs.unesp.br/index.php/revista_proex/article/view/1874

19. Papathanasiou IV, Tsaras K, Sarafis P. Views and perceptions of nursing students on their clinical learning environment: teaching and learning. Nurse Educ Today. 2014;34(1):57-60. doi: 10.1016/j.nedt.2013.02.007

20. Paulino VCP, Silva LA, Prado LAS. Barbosa M, Porto CC. Training and skills for teaching in nursing undergraduate courses. J Health NPEPS [Internet]. 2017 [cited 2019 May 06];2(1):272-84. Available from: https://periodicos.unemat.br/index.php/jhnpeps/article/view/1822

21. Cruz RAO, Araujo ELM, Nascimento NM, Lima RJ, França JRF, Oliveira JS. Reflections in the light of the complexity theory and nursing education. Rev Bra Enferm. 2017;70(1):224-7. doi: 10.1590/0034-7167-2016-0239

22. Omer TA, Suliman WA, Moola S. Roles and responsibilities of nurse preceptors: perception of preceptors and precetees. Nurse Educ Pract. 2016;16(1):54-9. doi: 10.1016/j.nepr.2015.07.005

23. Meira MDD, Kurcgant P. Nursing education: training evaluation by graduates, employers and teachers. Rev Bras Enferm. 2016;69(1):10-5. doi: $10.1590 / 0034-7167.2016690102$

24. Santos SVM, Ribeiro ME, Motta ALC, Silva JA, Resck ZMR, Terra FS. Building knowledge in nursing: a reflective theoretical and methodological approach for nurses training. Rev Enferm UFPE [Internet]. 2016 [cited 2019 May 06];10(1):172-8. Available from: https:// periodicos.ufpe.br/revistas/revistaenfermagem/article/view/10935

25. Ministério da Educação e Cultura (BR). Resolução CN/CES n 3, de 7 de novembro de 2001. Institui Diretrizes Curriculares Nacionais de Graduação em Enfermagem [Internet]. Brasília; 2001 [cited 2020 Mar 23]. Available from: http://portal.mec.gov.br/cne/arquivos/pdf/CES03.pdf

26. Cunha KS, Kahl C, Koerich C, Santos JLG, Lanzoni GM, Erdmann. University management: contributions for nurses who are faculty members and managers. Rev Bras Enferm;70(5):1125-31. doi: 10.1590/0034-7167-2017-0068

27. Souto BLC, Beck CLC, Trindade LR, Silva RM, Backes DS, Bastos RA. The teaching work in the post-graduation program: pleasure and suffering. Rev Enferm UFSM [Internet]. 2017 [cited 2019 May 06];7(1):29-39. Available from: https://periodicos.ufsm.br/reufsm/article/ view/22871/pdf

28. Lazzari DD, Martini JG, Busana JA. Teaching in higher education in nursing: an integrative literature review. Rev Gaúch Enferm. 2015;36(3):93-101. doi: 10.1590/1983-1447.2015.03.49670

29. Peres CRFB, Marin MJS, Tonhom SFR, Marques MLSF. Current challenges in nursing education: the professor's perspective. Rev Rene. 2018;19e3160. doi: 10.15253/2175-6783.2018193160

30. Lúanaigh PO. Becoming a professional: what is the influence of registered nurses on nursing students' learning in the clinical environment? Nurse Educ Prac. 2015;15(6):450-6. doi: 10.1016/j.nepr.2015.04.005

31. Al-Ghareeb AZ, Cooper SJ. Barriers and enablers to the use of high-fidelity patient simulation manikins in nurse education: an integrative review. Nurse Educ Today. 2016;36(s1):281-286. doi: 10.1016/j.nedt.2015.08.005 